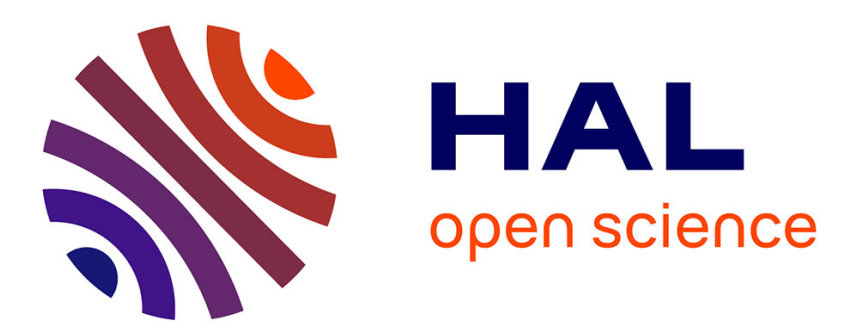

\title{
Selection of Electrode Area for Electrochemical Noise Measurements to Monitor Localized CO2 Corrosion
}

Xiu Jiang, Srdjan Nesic, François Huet, Brian Kinsella, Bruce Brown, David Young

\section{- To cite this version:}

Xiu Jiang, Srdjan Nesic, François Huet, Brian Kinsella, Bruce Brown, et al.. Selection of Electrode Area for Electrochemical Noise Measurements to Monitor Localized CO2 Corrosion. Journal of The Electrochemical Society, 2012, 159 (7), pp.C283-C288. 10.1149/2.007207jes . hal-00783527

\section{HAL Id: hal-00783527 \\ https://hal.sorbonne-universite.fr/hal-00783527}

Submitted on 1 Feb 2013

HAL is a multi-disciplinary open access archive for the deposit and dissemination of scientific research documents, whether they are published or not. The documents may come from teaching and research institutions in France or abroad, or from public or private research centers.
L'archive ouverte pluridisciplinaire HAL, est destinée au dépôt et à la diffusion de documents scientifiques de niveau recherche, publiés ou non, émanant des établissements d'enseignement et de recherche français ou étrangers, des laboratoires publics ou privés. 


\title{
Selection of Electrode Area for Electrochemical Noise Measurements to Monitor Localized $\mathrm{CO}_{2}$ Corrosion
}

\author{
Xiu Jiang ${ }^{a, b}$, Srdjan Nešić ${ }^{a^{*}}$, François Huet ${ }^{c}$, Brian Kinsella ${ }^{a}$, Bruce Brown ${ }^{a}$, David Young ${ }^{a}$ \\ ${ }^{a}$ Institute for Corrosion and Multiphase Technology, Department of Chemical and Biomolecular \\ Engineering, Ohio University, Athens, OH 45701, USA
}

${ }^{\mathrm{b}}$ Sinopec Research Institute of Safety Engineering, No.218, Yan $\operatorname{an} 3{ }^{\text {rd }}$ RD, Qingdao, Shandong, 266071, P.R.China

${ }^{\mathrm{c}}$ Université Pierre et Marie Curie-Paris6, Laboratoire Interfaces et Systèmes Electrochimiques; CNRS, UPR15-LISE, 4 place Jussieu, 75252 Paris Cedex 05, France

\begin{abstract}
The simultaneous fluctuations of potential noise and current noise between two nominally identical X-65 mild steel electrodes were recorded using a ZRA (Zero Resistance Ammeter) to monitor localized $\mathrm{CO}_{2}$ corrosion in $\mathrm{CO}_{2}$-saturated $1 \mathrm{wt} \% \mathrm{NaCl}$ solution at $80^{\circ} \mathrm{C}$. Electrochemical noise $(\mathrm{EN})$ was obtained from both $11.6 \mathrm{~cm}^{2}$ and $1 \mathrm{~cm}^{2}$ specimens to understand how the surface area affects EN signals. Linear polarization resistance (LPR) measurements were conducted to investigate the general $\mathrm{CO}_{2}$ corrosion behavior. Surface morphologies and pit depths were observed by scanning electron microscopy (SEM) and infinite focus microscopy (IFM) for 3D optical analysis. The results showed that the electrode area significantly influenced the EN signals of localized $\mathrm{CO}_{2}$ corrosion. Transients related to metastable pitting were best observed with $1 \mathrm{~cm}^{2}$ specimens but not clearly obtained for $11.6 \mathrm{~cm}^{2}$ specimens.
\end{abstract}

Keywords: $\mathrm{CO}_{2}$ corrosion, electrochemical noise, electrode size, pitting, transient

\section{INTRODUCTION}

$\mathrm{CO}_{2}$ corrosion of steel pipelines has been one of the most common corrosion problems in the oil and gas industry. Mild steel is widely used in the construction of pipelines in spite of its low corrosion resistance, which is probably due to its well developed technology and cost effective characteristics. When $\mathrm{CO}_{2}$ dissolves in water, carbonic acid is formed, which has been found to be more corrosive to mild steel than $\mathrm{HCl}$ of same $\mathrm{pH} .{ }^{1}$

During the $\mathrm{CO}_{2}$ corrosion processes, corrosion product that is mostly iron carbonate $\left(\mathrm{FeCO}_{3}\right)$, may precipitate on the surface of the steel forming a film which could significantly reduce corrosion rate. Any damage to the corrosion product film, for example, by mechanical forces and chemical dissolution or the combination of both, is sometimes followed by severe corrosion attacks. ${ }^{2,3}$ Despite the failures that take place through localized corrosion, there are no techniques routinely used to detect the occurrence of localized corrosion in the field on a continuous basis.

\footnotetext{
${ }^{*}$ Corresponding author, Tel.: 1-740-593-9945; fax: 1-740-593-9949.

E-mail address: nesic@ohio.edu (S. Nesic).
} 
The random fluctuation of the current/potential observed under potentiostatic/galvanostatic control, often called electrochemical noise (EN), has received considerable attention, especially in the corrosion engineering field, since the early works of Iverson ${ }^{4}$ and Tyagai. ${ }^{5}$ Analysis of the spontaneous fluctuations of potential and current obtained from this method is used for distinguishing between different corrosion processes taking place, because each type of corrosion (for example general corrosion, pitting, crevice, and stress corrosion cracking) can have a characteristic fingerprint $\square$ or $\checkmark$ signature $\square$ in the noise signal. This fingerprint $\square$ can be used to identify the type of corrosion occurring and help to evaluate its severity. Traditional electrochemical techniques such as the linear polarization resistance, electrochemical impedance, etc., can not provide this kind of information. ${ }^{6-7}$ Therefore, most of the work on EN has been focused on localized corrosion.

Failure of pipelines in the oil and gas industry due to internal $\mathrm{CO}_{2}$ corrosion results largely from localized corrosion (pitting, weld, flow induced corrosion etc) rather than general corrosion. General corrosion processes involve a large number of corrosion events at low amplitude on the whole electrode area. The power spectral density (PSD) of current noise is proportional to the surface area, while the PSD of the potential noise is inversely proportional to the surface area. Thus, large electrodes are preferable for measuring electrochemical current noise and small electrodes are preferable for measuring electrode potential noise.$^{6-7}$ However, it is unclear if this conclusion can be used for localized corrosion, for example, pitting corrosion.

Small electrodes are usually used in the laboratory to simulate the corrosion occurring on large structures. Localized corrosion can be spatially distributed, this advocates for the use of very large electrodes. However, the use of large electrode is not convenient in the laboratory and localized corrosion is less likely to occur on the small probes than on large structures. Therefore, the choice of the electrode size is a particular challenge with respect to the use of $\mathrm{EN}$ for corrosion monitoring in service.

The objective of this study is to ascertain the effect of the surface area on EN signal when localized $\mathrm{CO}_{2}$ corrosion occurs.

\section{EXPERIMENTAL PROCEDURES}

The glass cell set-up is shown in Figure 1. All the experiments were undertaken in $1 \% \mathrm{NaCl}$ electrolyte solution and prior to each experiment, the solution was deaerated by bubbling $\mathrm{CO}_{2}$ gas for 1 hour, and this was continued throughout the experiment. The temperature was always maintained at $80^{\circ} \mathrm{C}$, the total pressure at 1 bar and $\mathrm{pH}$ monitored with an electrode immersed in the electrolyte. $\mathrm{Fe}^{2+}$ concentration was measured twice every day via a spectrophotometric method.

X65 mild steel was used as the test material for this experiment. The steel sheet was cut into five rectangular specimens of dimensions $(5.08 \times 2.29 \times 1.02 \mathrm{~cm})$ and two square specimens of dimensions $(1 \times 1 \times 1.02 \mathrm{~cm})$. Prior to immersion, the specimens were abraded with 240,400 and 600 grit SiC paper, and then rinsed with alcohol. Two of the rectangular specimens $\left(11.6 \mathrm{~cm}^{2}\right)$ and the two $1 \mathrm{~cm}^{2}$ specimens were used for EN measurement while the other three rectangular specimens were used for SEM study. The test duration lasted for 10 days.

The electrochemical measurements were performed using a Gamry Instruments PC4-series G-300 potentiostat. The zero-resistance ammeter (ZRA) mode was used for the EN measurement. Potential noise and current noise were collected simultaneously using two identical working electrodes and a saturated calomel electrode (SCE) reference electrode. The reference electrode was connected externally to the cell via a Luggin capillary tube and a porous tip. The readings were taken at 1 second sampling interval. A period of $1024 \mathrm{~s}$ was set for each noise recording run. A two-order polynomial fitting method 
was used for DC trend removal. The corresponding PSD was calculated with the periodogram method based on the fast Fourier transform. ${ }^{8}$

The linear polarization resistance (LPR) measurements were conducted by polarizing the working electrode $\pm 5 \mathrm{mV}$ vs. the open-circuit potential at a rate of $0.125 \mathrm{mV} / \mathrm{s}$. The solution resistance was measured using the EIS technique, and the measured $R_{p}$ was then corrected. EIS measurement was carried out by applying an oscillating potential of $\pm 5 \mathrm{mV}$ around the free corrosion potential to the working electrode using the frequency range $10 \mathrm{kHz}$ to $1 \mathrm{~Hz}$. After the specimens were removed from the cell, they were immediately rinsed, dried, and then stored in a desiccator. The surface morphology of the specimens was analyzed by SEM. 3D optical analysis of pits depth was done by Infinite Focus Microscopy (IFM). The experiment involved the following three separate experimental steps:

\section{Step 1: Formation of a corrosion product layer}

At the start of the experiment, deoxygenated aqueous sodium hydrogen carbonate and deoxygenated ferrous chloride solution were injected into the $1 \% \mathrm{NaCl}$ solution to adjust the $\mathrm{pH}$ to 6.3 and to obtain a saturation (S) of 150, with respect to iron carbonate. The steel specimens were inserted into the electrolyte solution and the condition was maintained for approximately 3.5 days, during which the supersaturation of the solution decreased as the precipitation and deposition of iron carbonate $\left(\mathrm{FeCO}_{3}\right)$ proceeded. This led to a significant reduction in the corrosion rate of the mild steel specimens.

\section{Step 2. Partial dissolution of the corrosion product layer}

Once the protective corrosion product layer was formed, the solution $\mathrm{pH}$ was adjusted to 5.0 using hydrochloric acid and the solution saturation with respect to $\mathrm{FeCO}_{3}$ was adjusted to 0.04 (undersaturation). This resulted in the dissolution of the $\mathrm{FeCO}_{3}$ corrosion product. This condition was maintained for only 4 hours in order to achieve a partial dissolution of the corrosion product layer.

\section{Step 3: Localized corrosion}

Following the partial dissolution of the protective corrosion product layer, the saturation of $\mathrm{FeCO}_{3}$ was then adjusted to the so-called grey zone ${ }^{9} \square$ around unity (in reality $0.5 \square 2.0$ ) using a sodium based ion exchange resin, where the corrosion product layer is neither bound to dissolve or precipitate rapidly. This process was kept for 6.5 days.

\section{RESULTS AND DISCUSSION}

\section{LPR results and surface analysis}

Saturation of $\mathrm{FeCO}_{3}$ and the corresponding evolution of the general corrosion rate with time in the $1 \% \mathrm{NaCl}$ solution are shown in Figure 2. Saturation of $\mathrm{FeCO}_{3}$ decreased with time during the first 3.5 days (film building process) because of the gradual deposition of $\mathrm{FeCO}_{3}$ onto the metal surface. General corrosion rates were calculated from LPR measurements assuming a $B$ constant of $0.013 \mathrm{~V} / \mathrm{decade}$. The corrosion rate decreased during the first 3.5 days because of the film building, and then increased when the corrosion product film was partially dissolved.

The surface morphology of the metal in the presence and in the absence of the $\mathrm{FeCO}_{3}$ film, which was removed by using a Clarke solution, is shown in Figure 3 after 10 days of exposure in the solution. Pitting was observed in both cases, and the pit depth of some pits measured by IFM was around $40 \mu \mathrm{m}$. 


\section{EN results on small specimens $\left(1 \mathrm{~cm}^{2}\right)$}

Typical time records of potential and current noises for $1 \mathrm{~cm}^{2}$ specimens in the $1 \% \mathrm{NaCl}$ solution are shown in Figure 4 and Figure 5 after different times of exposure. The typical signal of transients related to metastable pitting for carbon stee ${ }^{10}$ can be observed in Figure 5 after 6 days of exposure. The sudden rise and gradual drop in current noise was accompanied by a sudden drop and gradual rise in potential noise, indicating the breakdown of the mild steel corrosion product layer, followed by a recovery. ${ }^{6}$ Curiously, all current transients in the time record of the current noise after 7.5 days of exposure were in the positive direction while half of them should be expected to occur on the negative direction. ${ }^{6-7}$ This was an indication that only one of the two specimens was corroding during this short period of time. However, at the end of the test, pits were actually present on both electrodes.

The variation of the current PSDs with time is shown in Figure 6. The amplitude of each current PSD was multiplied by a certain factor (shown in the Figure) to achieve more clarity. The current PSD amplitude increased with time because localized corrosion is associated with larger electrochemical events than uniform corrosion ${ }^{7}$. After 10 days it was about two decades higher than that observed after 3.5 days because of the occurrence of pitting corrosion, as shown in Figure 3.

The fact that the EN signals had been correctly sampled, without aliasing influence, was proved by the existence of a sharp PSD decrease above $0.4 \mathrm{~Hz}$ that was due to the anti-aliasing filter in the data acquisition system. In order to further show the validity of the EN measurements, time records were acquired at $1 \mathrm{~Hz}$ and $10 \mathrm{~Hz}$ sampling frequencies after 3.5 days of exposure in the $1 \% \mathrm{NaCl}$ solution. To calculate the PSD, a single time record sampled at $1 \mathrm{~Hz}$ and 10 time records sampled at $10 \mathrm{~Hz}$ were used. The good overlap of the PSDs at $1 \mathrm{~Hz}$ and $10 \mathrm{~Hz}$ in Figure 6 validated the EN measurement. All EN measurements reported in this paper were done following this procedure to ensure the validity of both the time records and PSDs.

The corrosion rate can also be estimated from the EN resistance, $R_{n}$, defined as the ratio of the voltage and current SDs, or from the low-frequency limit of the EN impedance, $Z_{n}$, defined as the square rooted ratio of the voltage and current PSDs. ${ }^{6,11}$ The variation of EN impedance with time for the $1 \mathrm{~cm}^{2}$ specimens in the $1 \% \mathrm{NaCl}$ solution is shown in Figure 7. $\mathrm{Z}_{\mathrm{n}}$ did not depend on the frequency below 0.1 $\mathrm{Hz}$ and slightly increased above $0.1 \mathrm{~Hz}$ during the 3.5 and 4 days of exposure, that is, before the occurrence of localized corrosion. This increase indicated that the potential noise, measured at that time, was due to the instrumentation noise of the voltage amplifier above $0.1 \mathrm{~Hz} .^{12}$ Indeed, since a true reference electrode was used (SCE), the noise impedance was expected to be equal to the impedance modulus of the electrodes, and the impedance modulus was not expected to increase with frequency in such systems. On the other hand, the plateau shown by $Z_{n}$ below $0.1 \mathrm{~Hz}$ indicated that the modulus of the electrode impedance was flat as well, and, therefore, the noise resistance was equal to the polarization resistance in that case. ${ }^{6}$

\section{EN results on big specimens $\left(11.6 \mathrm{~cm}^{2}\right)$}

Potential and current time records for $11.6 \mathrm{~cm}^{2}$ specimens are shown in Figure 8 and Figure 9 for various exposure times in the $1 \% \mathrm{NaCl}$ solution. The $\mathrm{EN}$ signals had the same change trend during the whole experiment. However, in contrast with the $1 \mathrm{~cm}^{2}$ specimens, the time records showed large and slow potential fluctuations (for example, starting at time $280 \mathrm{~s}$ in the 4-day time record), which were not correlated to the current fluctuations. The second major difference in the EN signals observed between the $11.6 \mathrm{~cm}^{2}$ and $1 \mathrm{~cm}^{2}$ specimens is that the characteristic signal of transients related to metastable 
pitting for carbon steel was not clearly observed at all after 6 days on the $11.6 \mathrm{~cm}^{2}$ specimens in Figure 9 , but it was well observed on the $1 \mathrm{~cm}^{2}$ specimens, as shown in Figure 5.

The variation of current PSDs with time, each of them calculated from a single time record for the $11.6 \mathrm{~cm}^{2}$ specimens, is shown in Figure 10. The same trend as for the $1 \mathrm{~cm}^{2}$ specimens was observed; the amplitude of the current PSDs increased with time because of the progressive appearance of pitting corrosion. The shape of the current PSDs, with a low-frequency plateau and a $1 / \mathrm{f}^{2}$ decrease, is identical to those measured on the small specimens, indicating that pitting corrosion actually occurred after 6 days.

The variation of $\mathrm{EN}$ impedance with time for the $11.6 \mathrm{~cm}^{2}$ specimens in the $1 \% \mathrm{NaCl}$ solution is shown in Figure 11. Careful examination of the figure indicated that the increase of $Z_{n}$ above $0.1 \mathrm{~Hz}$ was more significant than that for the $1 \mathrm{~cm}^{2}$ specimens, which indicated that the potential noise measured in that frequency range was due to the instrumentation noise. Another point was that $Z_{n}$, and therefore the modulus of the electrode impedance as well, did not show a plateau below $0.1 \mathrm{~Hz}$. Therefore, in that case the noise resistance was no longer equal to the polarization resistance. ${ }^{6}$

\section{Comparison of EN results on small and large specimens}

The evolution with time of the current and potential standard deviations (SD), calculated after removal of the DC drift in the time domain for the $11.6 \mathrm{~cm}^{2}$ and $1 \mathrm{~cm}^{2}$ specimens in the $1 \% \mathrm{NaCl}$ solution and their ratios are shown in Table 2. A higher current standard deviation was obtained for the $11.6 \mathrm{~cm}^{2}$ specimens during the whole experimental duration. However, the potential standard deviation for the $11.6 \mathrm{~cm}^{2}$ specimens was higher before 6 days and smaller after 7.5 days than that for the $1 \mathrm{~cm}^{2}$ specimens.

For general corrosion, the SD of the current noise is proportional to the square root of the surface area. ${ }^{10}$ However, it is unclear whether this conclusion can be drawn for localized corrosion, such as pitting corrosion, or not. The ratio $\sigma_{1} / \sigma_{2}$, where $\sigma_{1}$ and $\sigma_{2}$ denote the SD of the current noise of the large and small specimens, respectively, was compared to the square rooted ratio of the surface areas $\sqrt{11.6 / 1}$ $=3.4$. As shown in Table 2 , all the ratio values, except for the film partial dissolution process ( $4^{\text {th }}$ day), are close to 3.4, which indicates that the SD of the current noise was proportional to the square root of the surface area for both general corrosion and pitting corrosion. The reason why the ratio is not around 3.4 during the partial dissolution process needs to be further investigated.

Concerning the potential SD dependence on surface area, the large and slow potential fluctuations observed with the large specimens, the origin of which was not determined, gave a large contribution to the potential SD with unexpected large values during general corrosion (3.5 and 4 days). Indeed, for general corrosion the potential SD was expected to be proportional to the reciprocal of the square root of the electrode surface area while Table 2 showed smaller values of the potential SD for small specimens before 6 days of exposure. The $\sigma_{4} / \sigma_{3}$ value, where $\sigma_{3}$ and $\sigma_{4}$ were, respectively, the potential SDs of the $11.6 \mathrm{~cm}^{2}$ and $1 \mathrm{~cm}^{2}$ specimens, was lower than 3.4 at all days of exposure.

As indicated above, $Z_{n}$ was less flat for the $11.6 \mathrm{~cm}^{2}$ specimens (Figure 11) than that for the $1 \mathrm{~cm}^{2}$ specimens (Figure 7) below $0.1 \mathrm{~Hz}$, which was probably due to the large and slow potential fluctuations observed for the $11.6 \mathrm{~cm}^{2}$ specimens in Figure 8 and Figure 9. The average value of $Z_{n}$ below $0.1 \mathrm{~Hz}$ was calculated over the first 103 datapoints for both sizes of specimens. Table 3 shows the $R_{p}, Z_{n}$, and $R_{n}$ values for both sizes of specimens at various days of exposure in the $1 \% \mathrm{NaCl}$ solution. It must be noticed that the $R_{p}$ values of the $1 \mathrm{~cm}^{2}$ specimens were not saved during the experiment. Since both 
large and small specimens were immersed in the same glass cell, the $R_{p}$ values of the $1 \mathrm{~cm}^{2}$ specimens were obtained by multiplying the $R_{p}$ values of the large specimens by a surface area factor of 11.6. The $Z_{n}$ and $R_{n}$ values were qualitatively in good agreement for both electrode sizes. For the small specimens, the $R_{n}$ and $R_{p}$ values were also in rather good agreement but the $R_{p}$ values were significantly smaller than the $Z_{n}$ and $R_{n}$ values for the large specimens. As mentioned above, this was due to high values of $R_{n}$ and $Z_{n}$ caused by the large and slow potential fluctuations observed on the large specimens, which were not observed on the current fluctuations.

The fact that the typical transients related to metastable pitting for carbon steel were observed on the $1 \mathrm{~cm}^{2}$ specimens (Figure 5) while no such transients were clearly observed on the $11.6 \mathrm{~cm}^{2}$ specimens (Figure 9) could be explained using Figure $12 .{ }^{6}$ This figure shows simulated time records of exponential transients occurring randomly (Poisson process) at an average rate of $\lambda_{1}=1 \mathrm{~s}^{-1}$ and $\lambda_{2}=100 \mathrm{~s}^{-1}$, and their corresponding PSDs. It is clear that increasing the transient rate leads to a random signal in which the shape of the exponential transient is no longer visible. However, for such a Poisson process, increasing the transient rate does not change the shape of the PSD, only its amplitude increases by a factor $\lambda_{2} / \lambda_{1}$. For the same corrosive environment, it is more likely that more pitting events occurred, thus showing a higher transient rate on EN records for the $11.6 \mathrm{~cm}^{2}$ specimens. A large number of pitting elementary current transients overlapped for the $11.6 \mathrm{~cm}^{2}$ specimens, making it impossible to detect the exact shape of the transients within the time record. Therefore it was quite difficult to distinguish pitting corrosion and general corrosion from the EN signals on the large specimens. The small transient rate on $1 \mathrm{~cm}^{2}$ specimens allows a clearer identification of the transients related to localized corrosion events.

From this result, it can be concluded that, electrode area has great influence on the EN signals. It is therefore very important, that extreme care should be taken in choosing the probe surface area in the application of EN on the corrosion monitoring in the industry. It may cause totally misunderstanding of the inherent corrosion mechanism if the relationship between the electrode surface area and EN signals is not considered.

\section{CONCLUSIONS}

1. The EN technique was successful in providing in-situ information about the evolution of the localized $\mathrm{CO}_{2}$ corrosion process.

2. Localized corrosion was observed on both small and large specimens in a $\mathrm{NaCl}$ solution of $1 \%$ concentration.

3. The electrode area has a great influence on the EN signals. Current and potential transients related to metastable pitting can be best observed in the time records on small specimens. For large specimens, no typical pitting current transient is observable since all of them overlap and indirect information on the pitting rate must be derived from the magnitude of the current SD. Moreover, it is questionable to specify an area, since the significance of $\square$ small $\square$ or $\square$ large $\square$ area will depend on the frequency of pitting transients, which varies from a system to another. Hence, extreme care should be taken in choosing the probe surface area in the application of EN for monitoring corrosion in industrial applications.

4. Enlarging the electrode size has a tendency to increase the amplitude of the current noise, but to decrease that of the potential noise, which may cause difficulties for its measurement because of the instrumentation noise of the voltage amplifier in the data acquisition system. 


\section{ACKNOWLEDGMENTS}

The authors would like to acknowledge the companies who provided the financial support and technical guidance for this project. They are BP, Champion Technologies, Clariant, ConocoPhillips, Tenaris, Chevron, Baker Hughes, Baker Petrolite, PTTEP, Eni, OXY, ExxonMobil, Mi SWACO, NALCO, Saudi Aramco, Shell, Columbia Gas Transmission, and Total.

\section{REFERENCES}

1. C. de Waard and D.E. Milliams, Corrosion, 31, 177 (1975).

2. V. Ruzic, Mechanisms of protective $\mathrm{FeCO}_{3}$ film remove in single-phase flow-accelerated $\mathrm{CO}_{2}$ corrosion of mild steel $\square, \mathrm{PhD}$ thesis, The University of Queensland, 2006.

3. X. Jiang and S. Nesic, Electrochemical Investigation of the Role of $\mathrm{Cl}^{-}$on Localized $\mathrm{CO}_{2} \mathrm{Corrosion}$ of Mild Steel $\square, 17^{\text {th }}$ International Corrosion Congress, Las Vegas, NACE, 2008

4. W.P. Iverson, J. Electrochem. Soc., 115, 617 (1968).

5. V.A. Tyagai, Electrochim. Acta, 16, 1647(1971).

6. F. Huet, $\square$ The electrochemical noise technique $\square$ in $\square$ Analytical Methods in Corrosion Science and Engineering $\square$, eds. P. Marcus and F.Mansfeld, Taylor \& Francis, CRC Press, Series: Corrosion Technology, Volume 22, p. 507-570 (2006).

7. R.A. Cottis and S. Turgoose, Corrosion Testing Made Easy Electrochemical Impedance and Noise $\square$, NACE international, Chapter 7, 1999.

8. U. Bertocci, J. Frydman, C. Gabrielli, F. Huet, and M. Keddam, J. Electrochem. Soc., 145, 2780 (1998).

9. Y.F. Sun, K. Gorge, and S. Nesic, Paper 03327, NACE, 2003. (Houston, TX: NACE, 2003).

10. R.A. Cottis, Corrosion, 57, 265 (2000).

11. R.A. Cottis, M.A.A. Al-Awadhi, H. Al-Mazeedi, and S. Turgoose, Electrochim. Acta, 46, 3665 (2001).

12. U. Bertocci, F. Huet, J. Electrochem. Soc., 144, 2786 (1997). 
Table 1 Chemical composition of X-65 mild steel

\begin{tabular}{|l|l|l|l|l|l|l|l|l|l|l|}
\hline & $\mathrm{C}$ & $\mathrm{Mn}$ & $\mathrm{Si}$ & $\mathrm{P}$ & $\mathrm{S}$ & $\mathrm{Cr}$ & $\mathrm{Cu}$ & $\mathrm{Ni}$ & $\mathrm{Mo}$ & $\mathrm{A} 1$ \\
\hline $\mathrm{X}-65$ & 0.065 & 1.54 & 0.25 & 0.013 & 0.001 & 0.05 & 0.04 & 0.04 & 0.007 & 0.041 \\
\hline
\end{tabular}

Table 2 Current and potential standard deviations for $11.6 \mathrm{~cm}^{2}$ and $1 \mathrm{~cm}^{2}$ specimens and their ratios at various days of exposure in $1 \% \mathrm{NaCl}$ solution

\begin{tabular}{|c|c|c|c|c|c|c|c|}
\hline \multicolumn{2}{|c|}{ Time / days } & 3.5 & 4 & 6 & 7.5 & 9 & 10 \\
\hline $\begin{array}{c}\text { Current } \\
\text { Standard } \\
\text { Deviation }\end{array}$ & $\sigma_{1}\left(11.6 \mathrm{~cm}^{2}\right) / \mu \mathrm{A}$ & 0.08 & 0.36 & 0.16 & 1.3 & 0.92 & 0.84 \\
\cline { 2 - 8 } & $\sigma_{2}\left(1 \mathrm{~cm}^{2}\right) / \mu \mathrm{A}$ & 0.021 & 0.031 & 0.057 & 0.58 & 0.35 & 0.20 \\
\cline { 2 - 8 } & $\sigma_{1} / \sigma_{2}$ & 3.8 & 11.6 & 2.8 & 2.2 & 2.6 & 4.2 \\
\hline $\begin{array}{c}\text { Potential } \\
\text { Standard } \\
\text { Deviation }\end{array}$ & $\sigma_{3}\left(11.6 \mathrm{~cm}^{2}\right) / \mu \mathrm{V}$ & 110 & 190 & 150 & 200 & 63 & 130 \\
\cline { 2 - 8 } & $\sigma_{4}\left(1 \mathrm{~cm}^{2}\right) / \mu \mathrm{V}$ & 48 & 32 & 44 & 280 & 170 & 180 \\
\cline { 2 - 8 } & $\sigma_{4} / \sigma_{3}$ & 0.43 & 0.17 & 0.30 & 1.4 & 2.7 & 1.4 \\
\hline
\end{tabular}

Table 3. $R_{p}, Z_{n}$ and $R_{n}$ for $11.6 \mathrm{~cm}^{2}$ and $1 \mathrm{~cm}^{2}$ specimens at various days of exposure in $1 \% \mathrm{NaCl}$ solution

\begin{tabular}{|c|c|c|c|c|c|c|}
\hline \multicolumn{2}{|c|}{ Time / days } & 3.5 & 4 & 6 & 7.5 & 10 \\
\hline \multirow{3}{*}{$11.6 \mathrm{~cm}^{2}$} & $Z_{n} / \mathrm{k} \Omega$ & 0.71 & 0.22 & 0.42 & 0.08 & 0.10 \\
\cline { 2 - 7 } & $R_{n} / \mathrm{k} \Omega$ & 1.4 & 0.52 & 0.95 & 0.15 & 0.15 \\
\cline { 2 - 7 } & $R_{p} / \mathrm{k} \Omega$ & 0.20 & 0.056 & 0.044 & 0.049 & 0.045 \\
\cline { 2 - 7 } $1 \mathrm{~cm}^{2}$ & $Z_{n} / \mathrm{k} \Omega$ & 3.3 & 1.1 & 1.0 & 0.55 & 0.57 \\
\cline { 2 - 7 } & $R_{n} / \mathrm{k} \Omega$ & 2.3 & 1.0 & 0.73 & 0.48 & 0.85 \\
\cline { 2 - 7 } & $R_{p} / \mathrm{k} \Omega$ & 2.2 & 0.65 & 0.51 & 0.56 & 0.52 \\
\hline
\end{tabular}




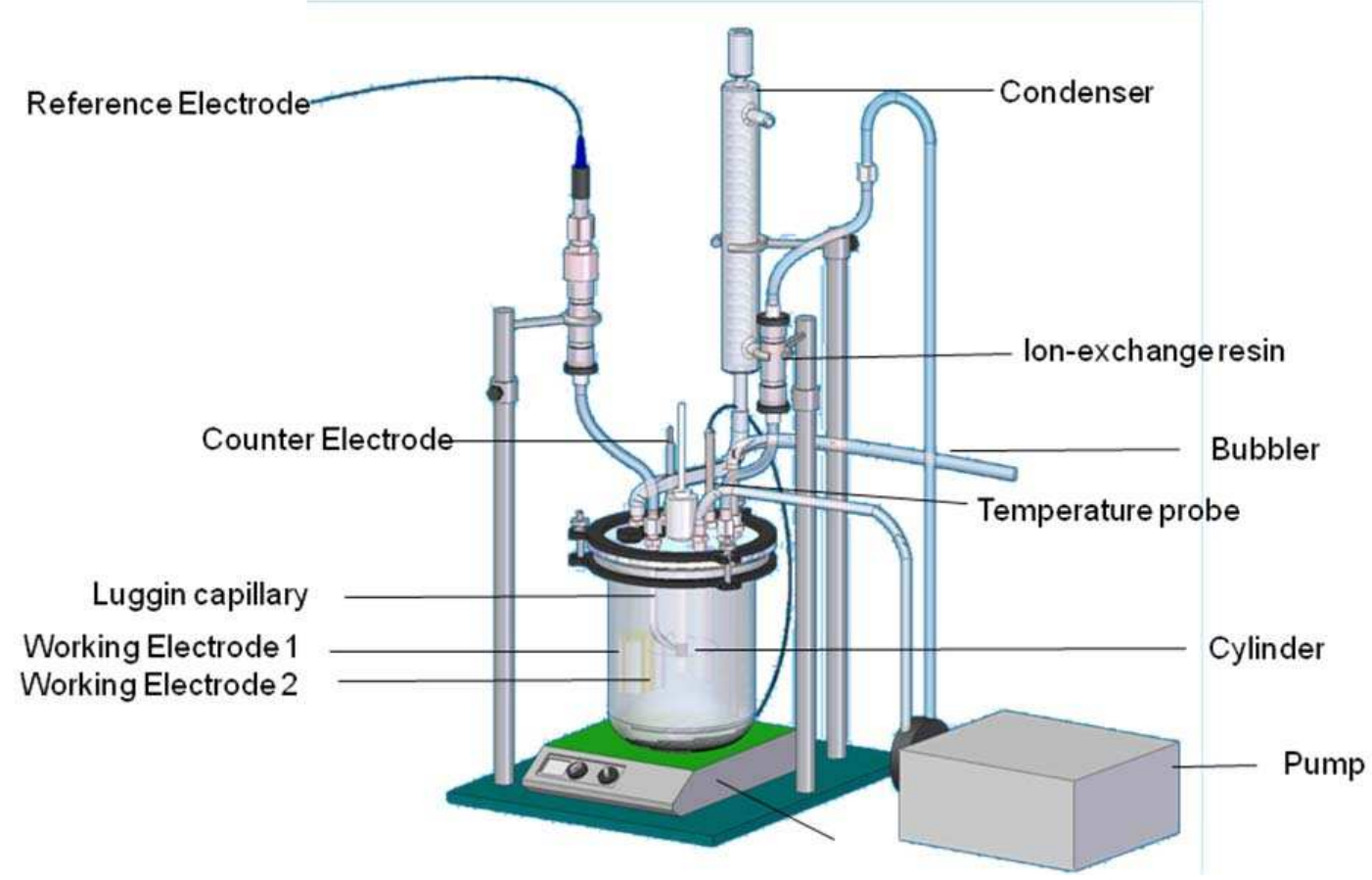

Figure 1. Glass cell set-up

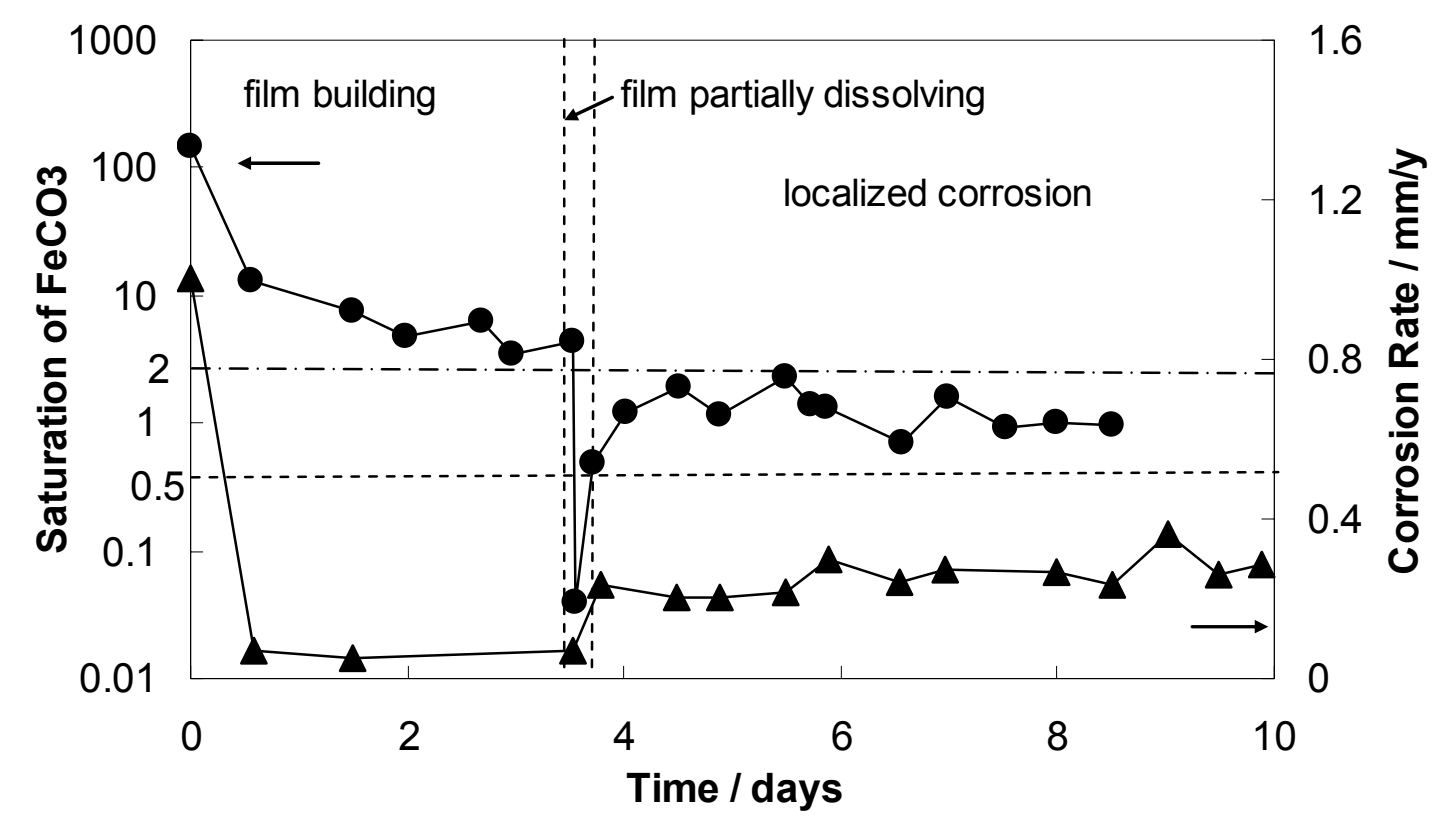

Figure 2. Saturation of $\mathrm{FeCO}_{3}$ and corrosion rate with time for $11.6 \mathrm{~cm}^{2}$ specimen in $1 \% \mathrm{NaCl}$ solution 


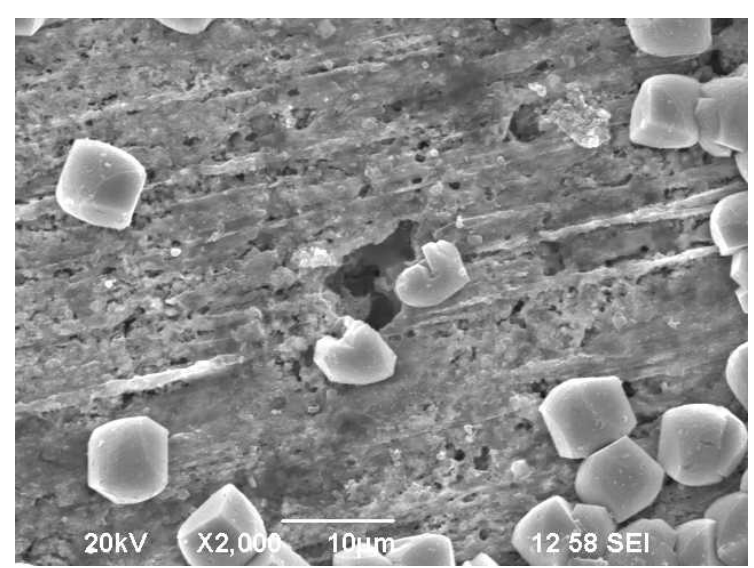

(a)

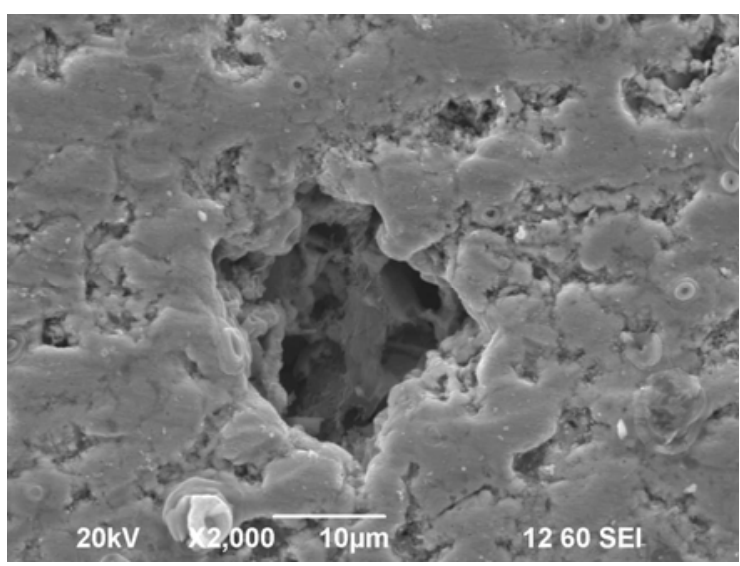

(b)

Figure 3. Surface morphology of metal with film ((a) and after film removal by using Clarke solution (b) after 10 days in $1 \% \mathrm{NaCl}$ solution

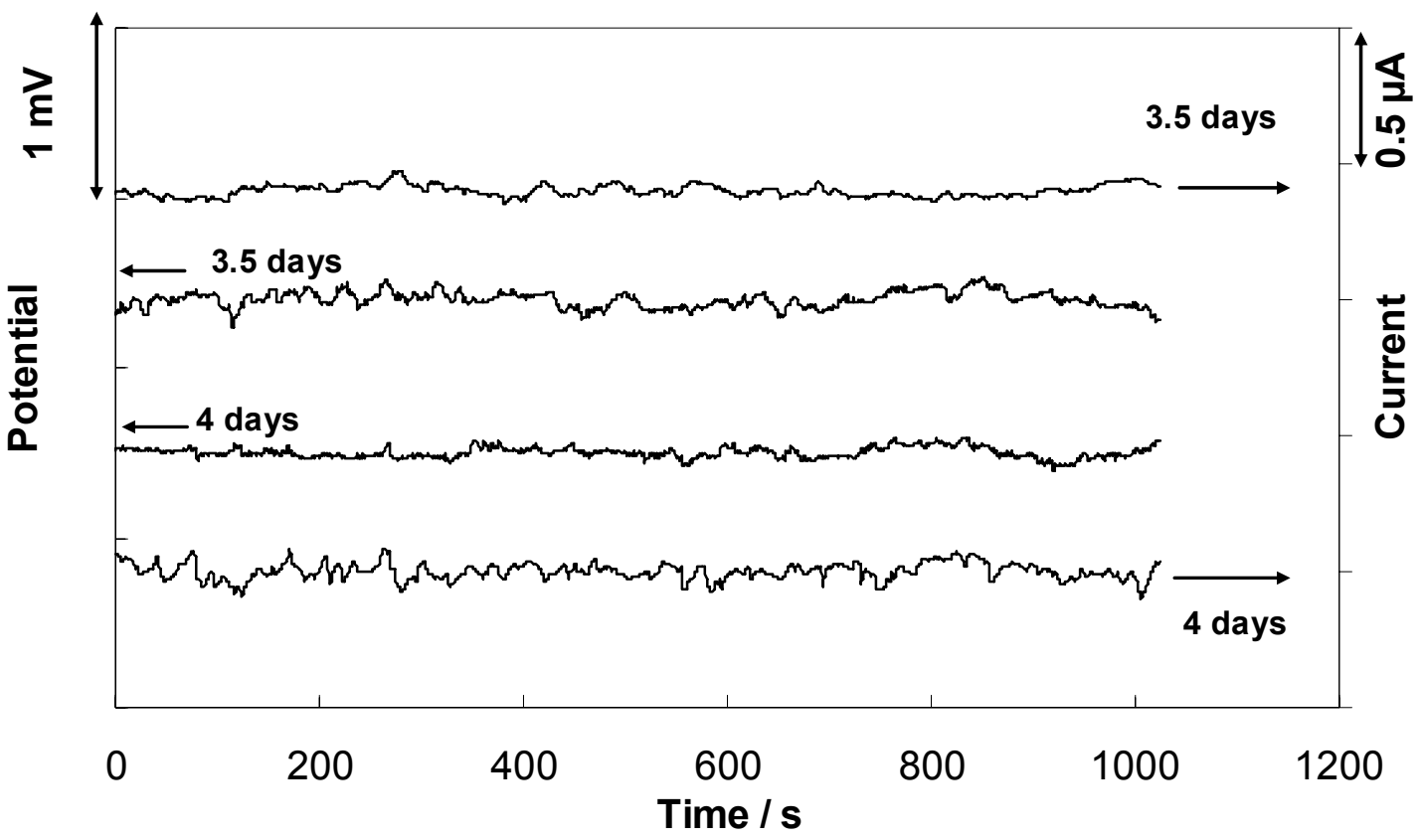

Figure 4. Potential noise and current noise after 3.5 days and 4 days for $1 \mathrm{~cm}^{2}$ specimens in $1 \% \mathrm{NaCl}$ solution after removing the DC drift with the polynomial fitting method 


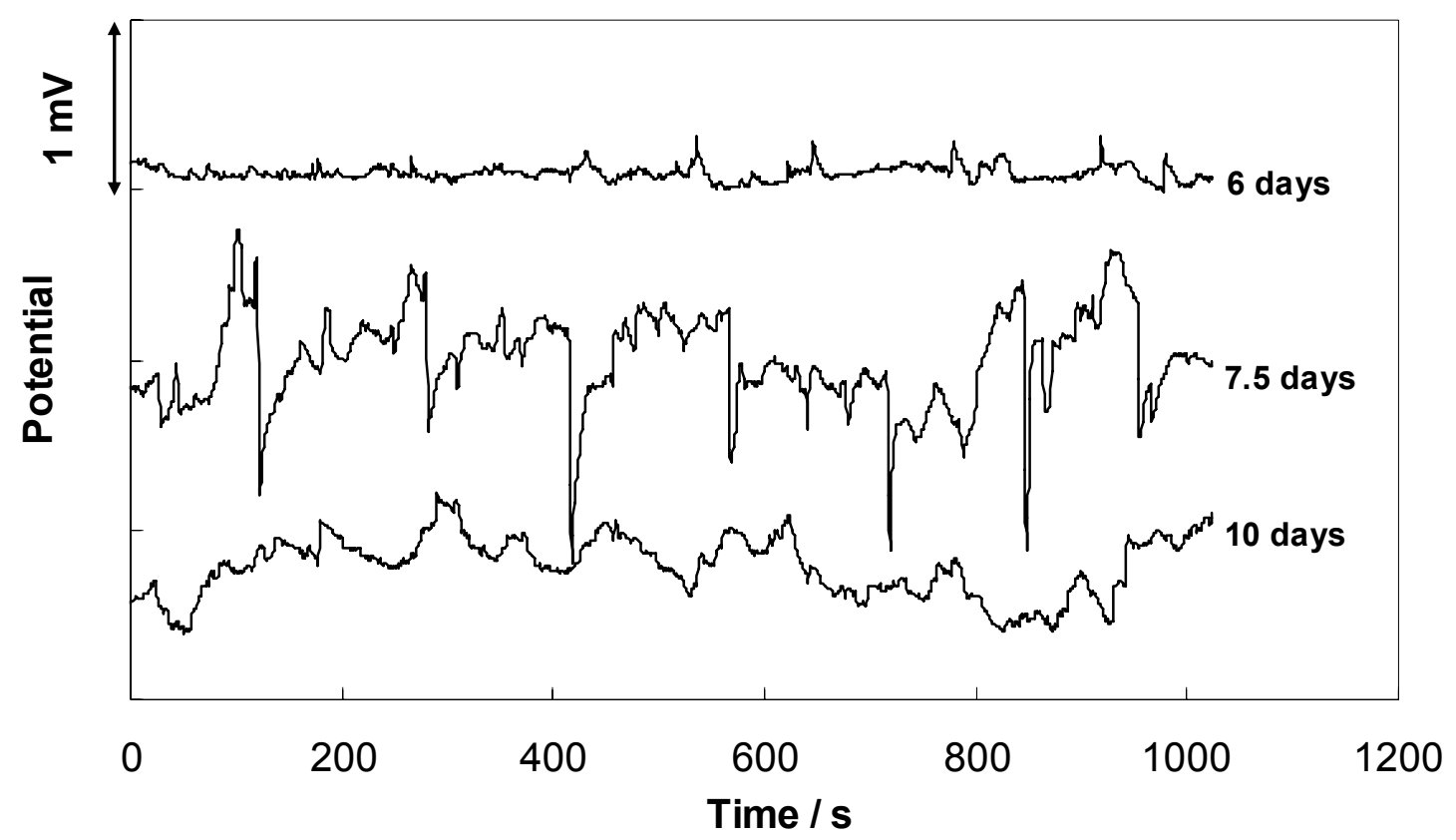

(a)

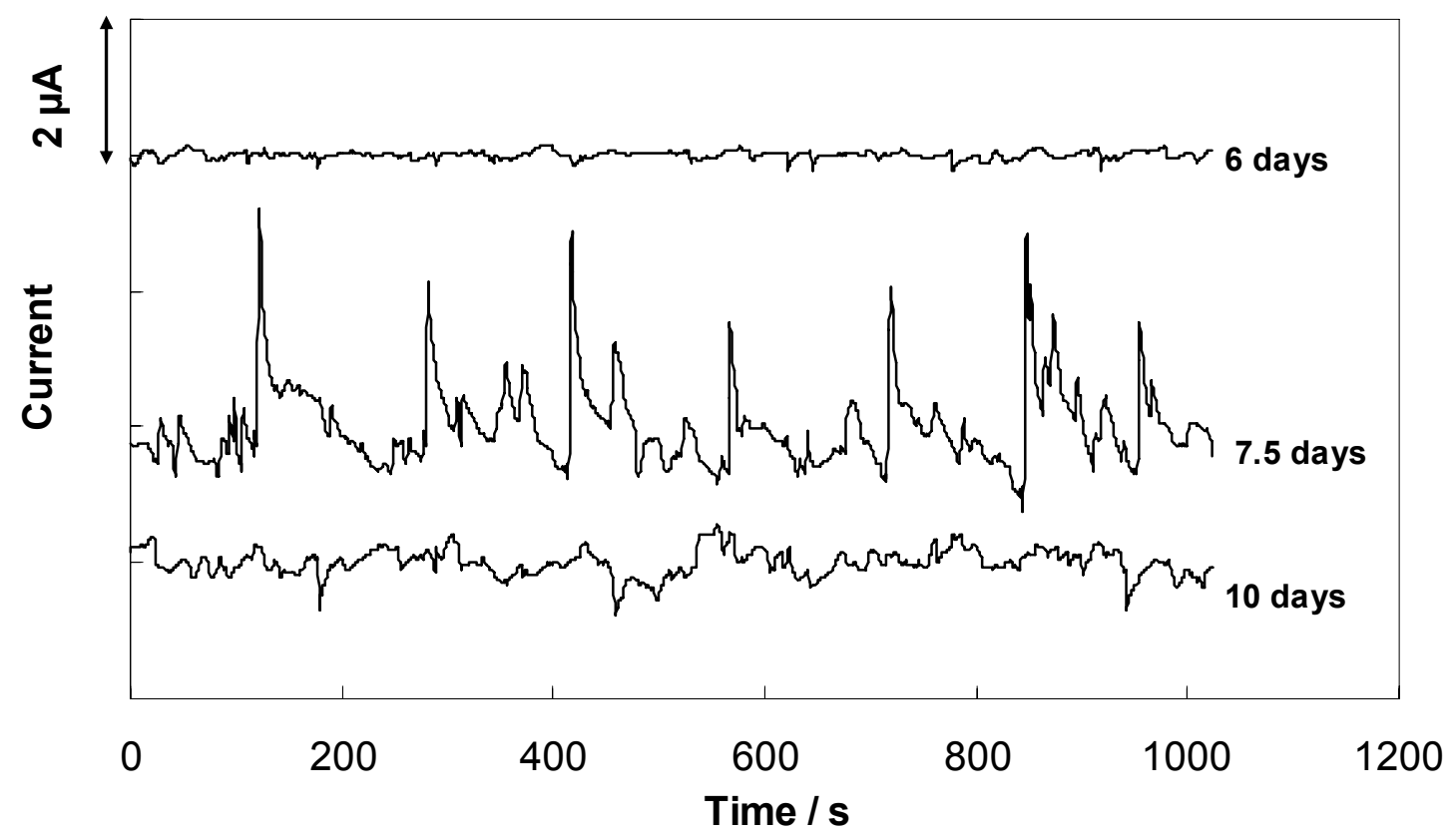

(b)

Figure 5. Potential noise(a) and current noise(b) after $6,7.5$ and 10 days for $1 \mathrm{~cm}^{2}$ specimens in $1 \%$ $\mathrm{NaCl}$ solution after removing the DC drift with the polynomial fitting method 


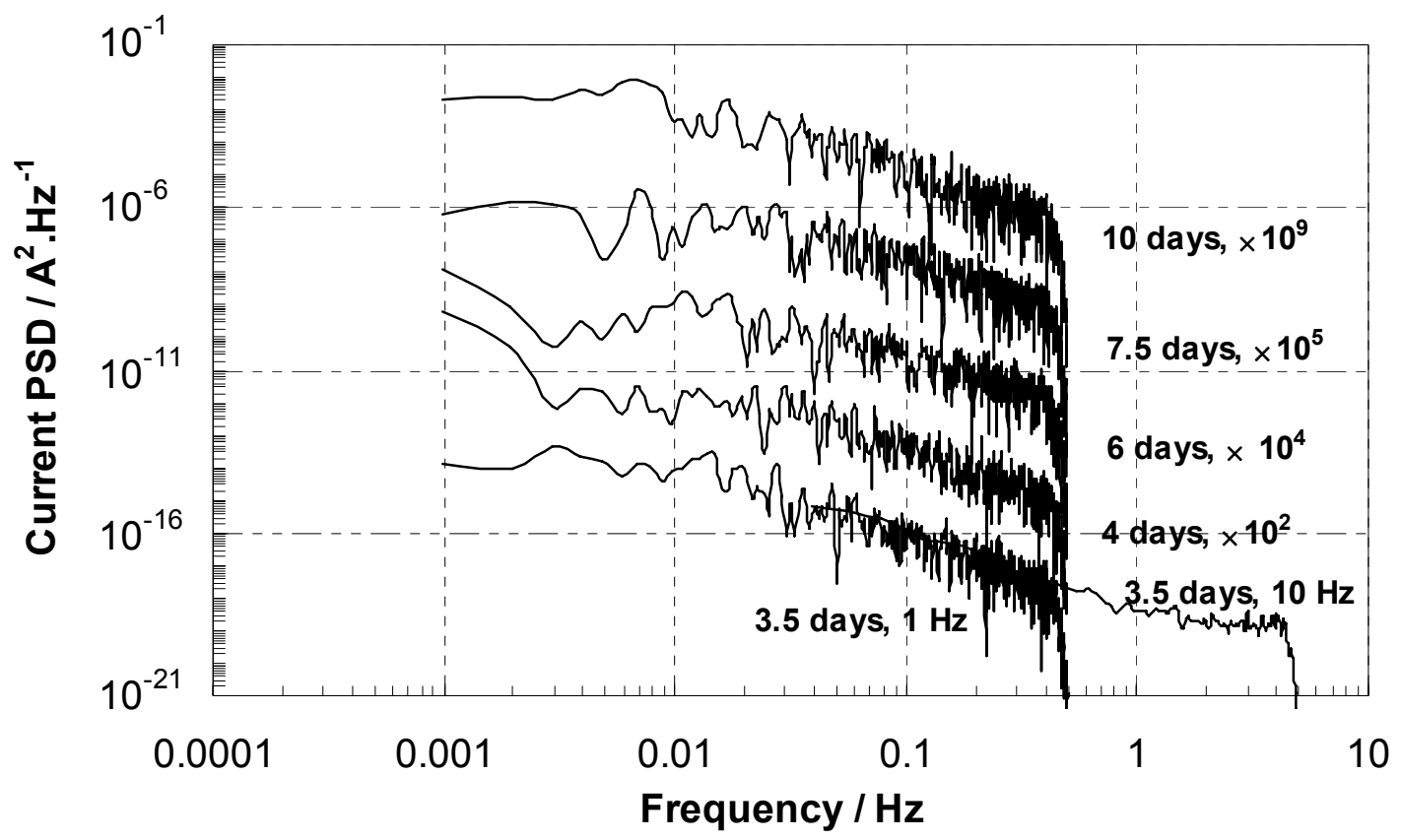

Figure 6. Current PSDs with time for $1 \mathrm{~cm}^{2}$ specimens in $1 \% \mathrm{NaCl}$ solution

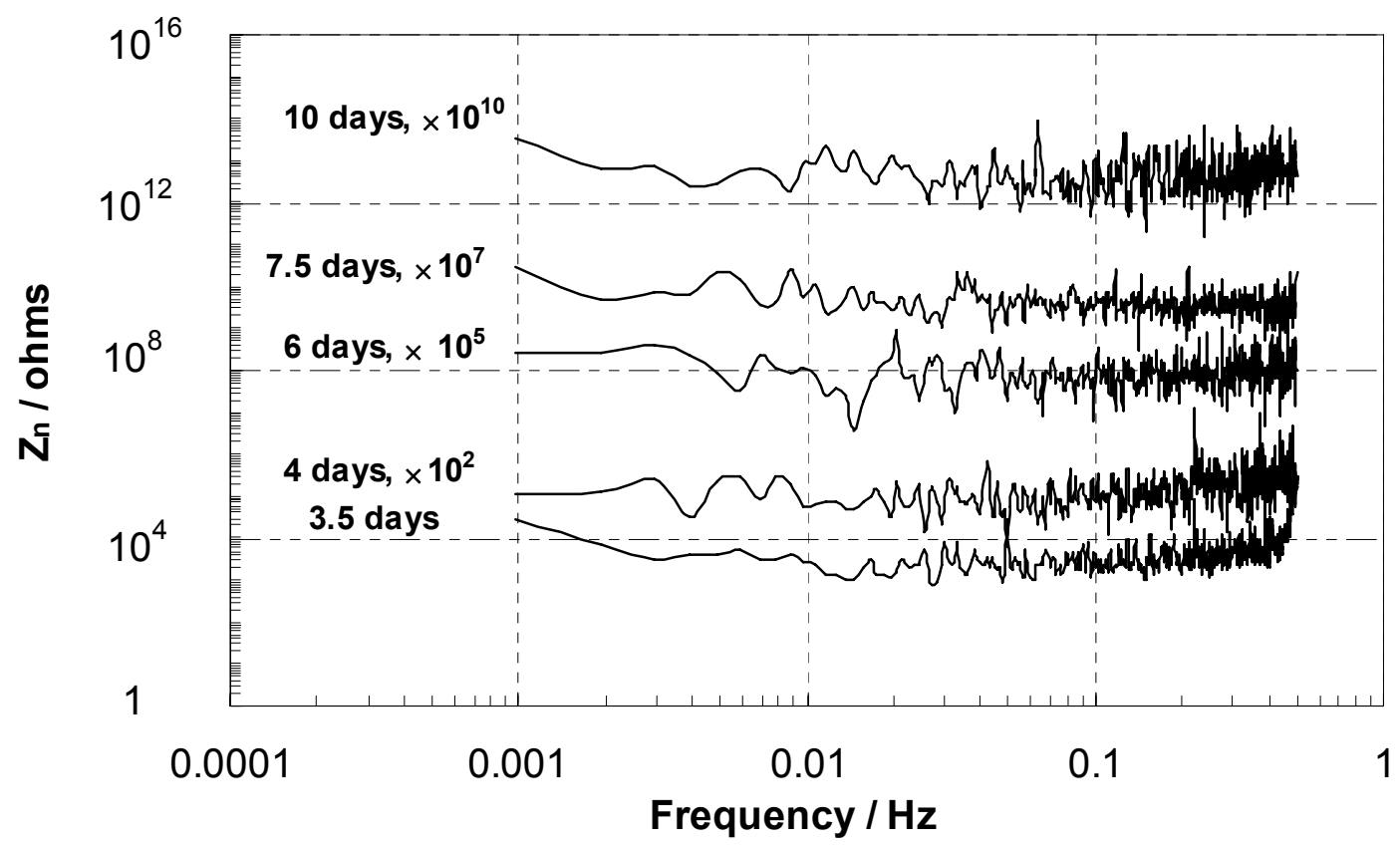

Figure 7. The variation of $Z_{n}$ with time for $1 \mathrm{~cm}^{2}$ specimens in $1 \% \mathrm{NaCl}$ solution 


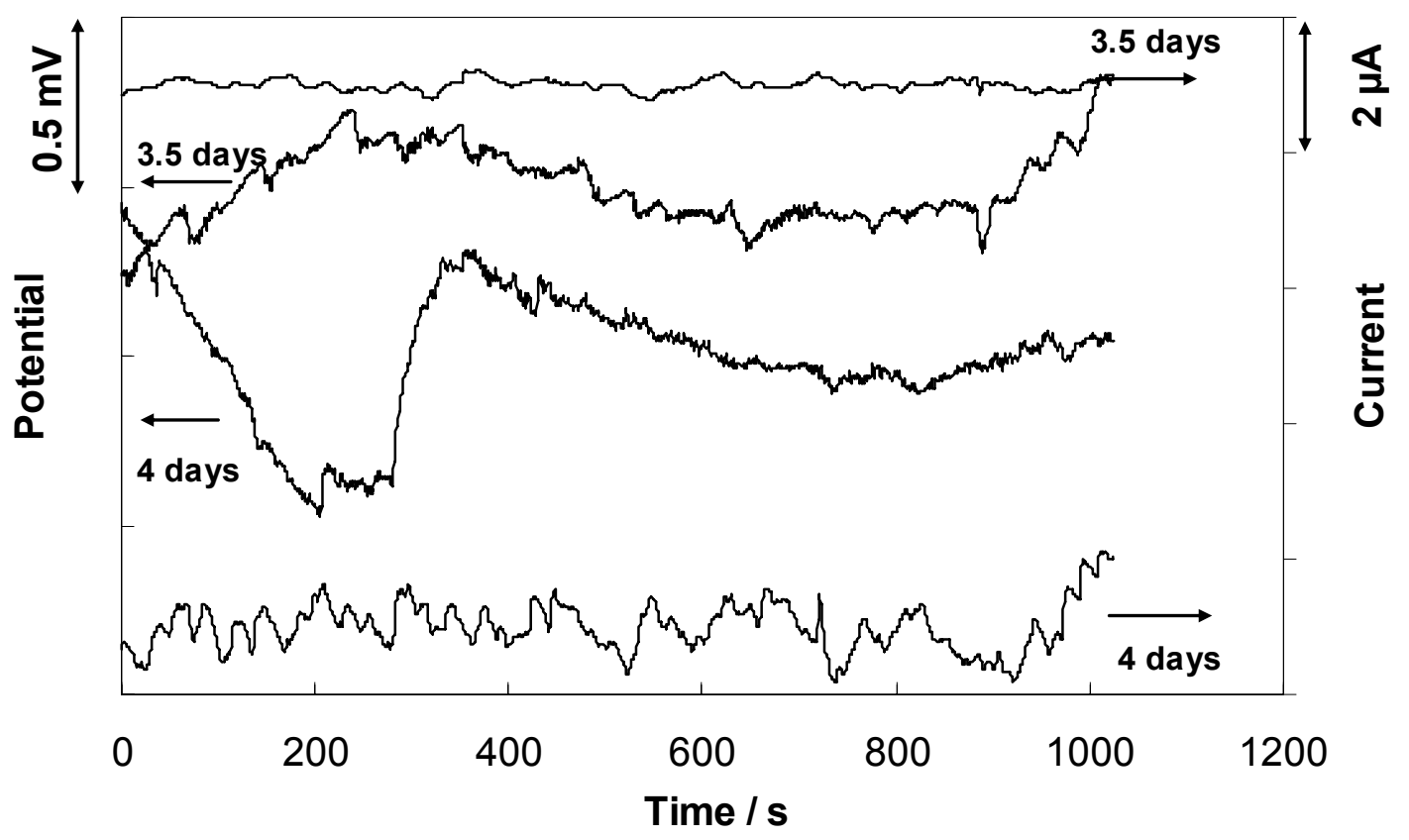

Figure 8. Potential noise and current noise after 3.5 days and 4 days for $11.6 \mathrm{~cm}^{2}$ specimens in $1 \% \mathrm{NaCl}$ solution after removing the DC drift with the polynomial fitting method 


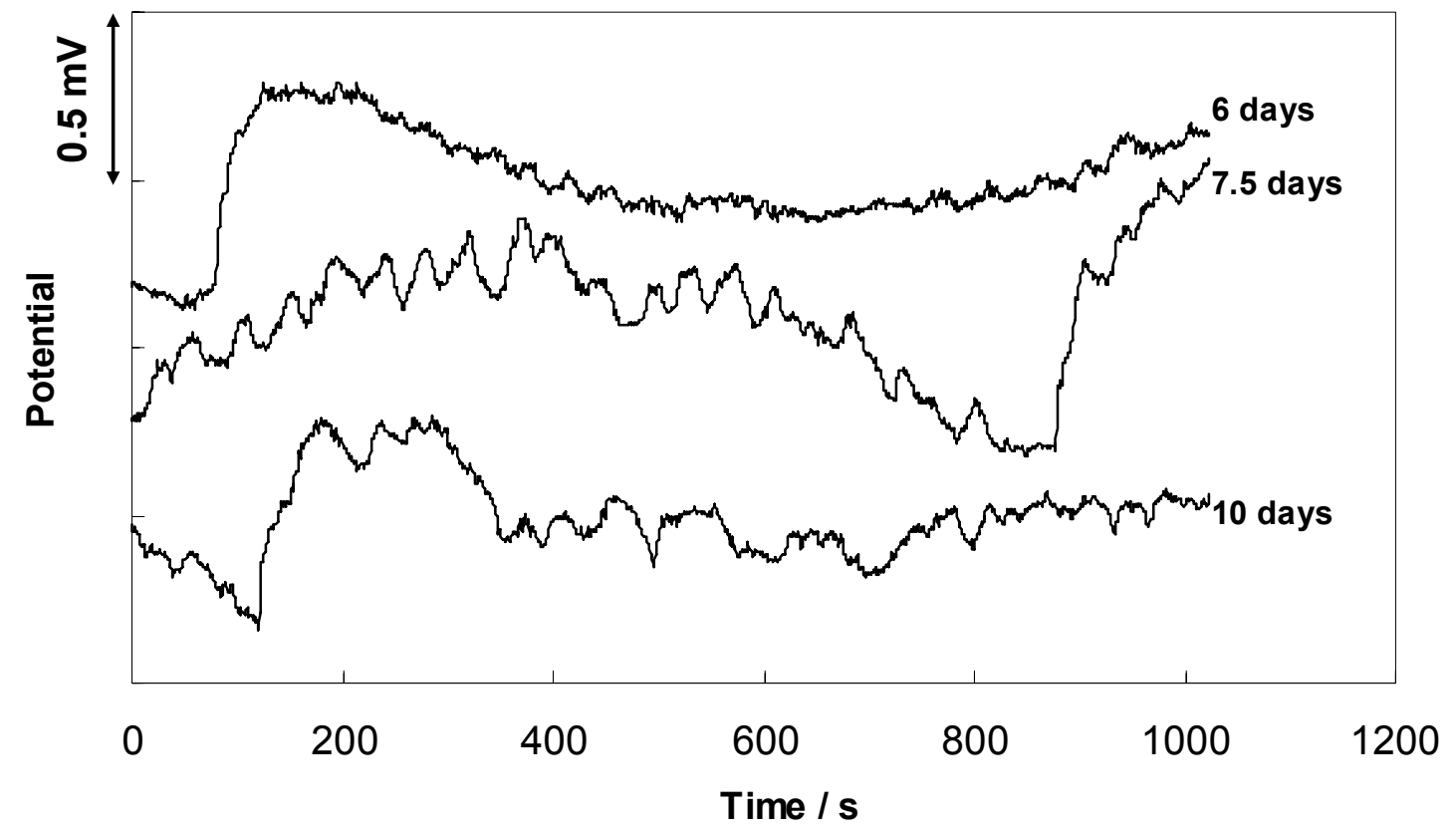

(a)

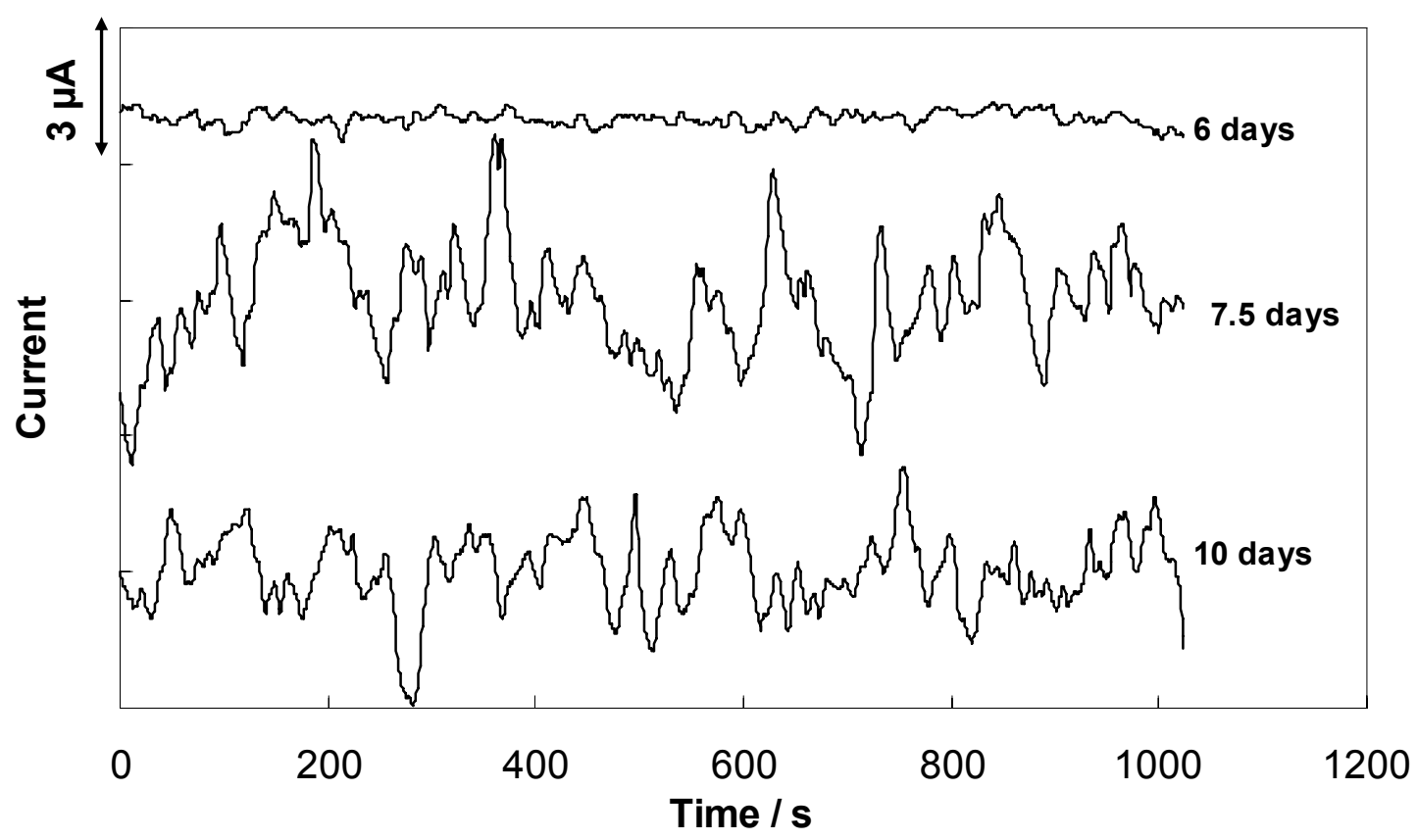

(b)

Figure 9. Potential noise(a) and current noise(b) after 6, 7.5 and 10 days for $11.6 \mathrm{~cm}^{2}$ specimens in $1 \%$ $\mathrm{NaCl}$ solution after removing the DC drift with the polynomial fitting method 


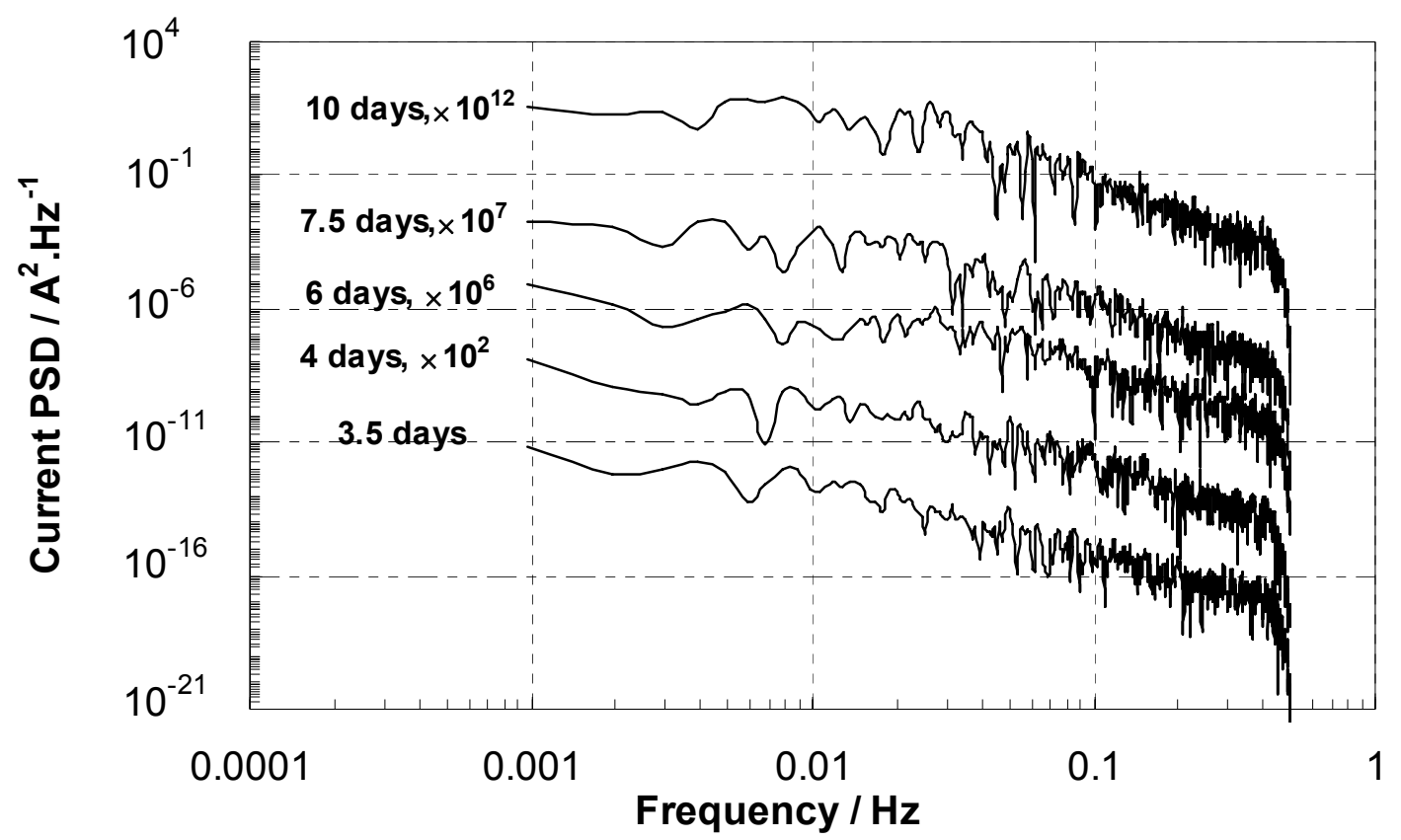

Figure 10. Current PSDs with time for $11.6 \mathrm{~cm}^{2}$ specimens in $1 \% \mathrm{NaCl}$ solution

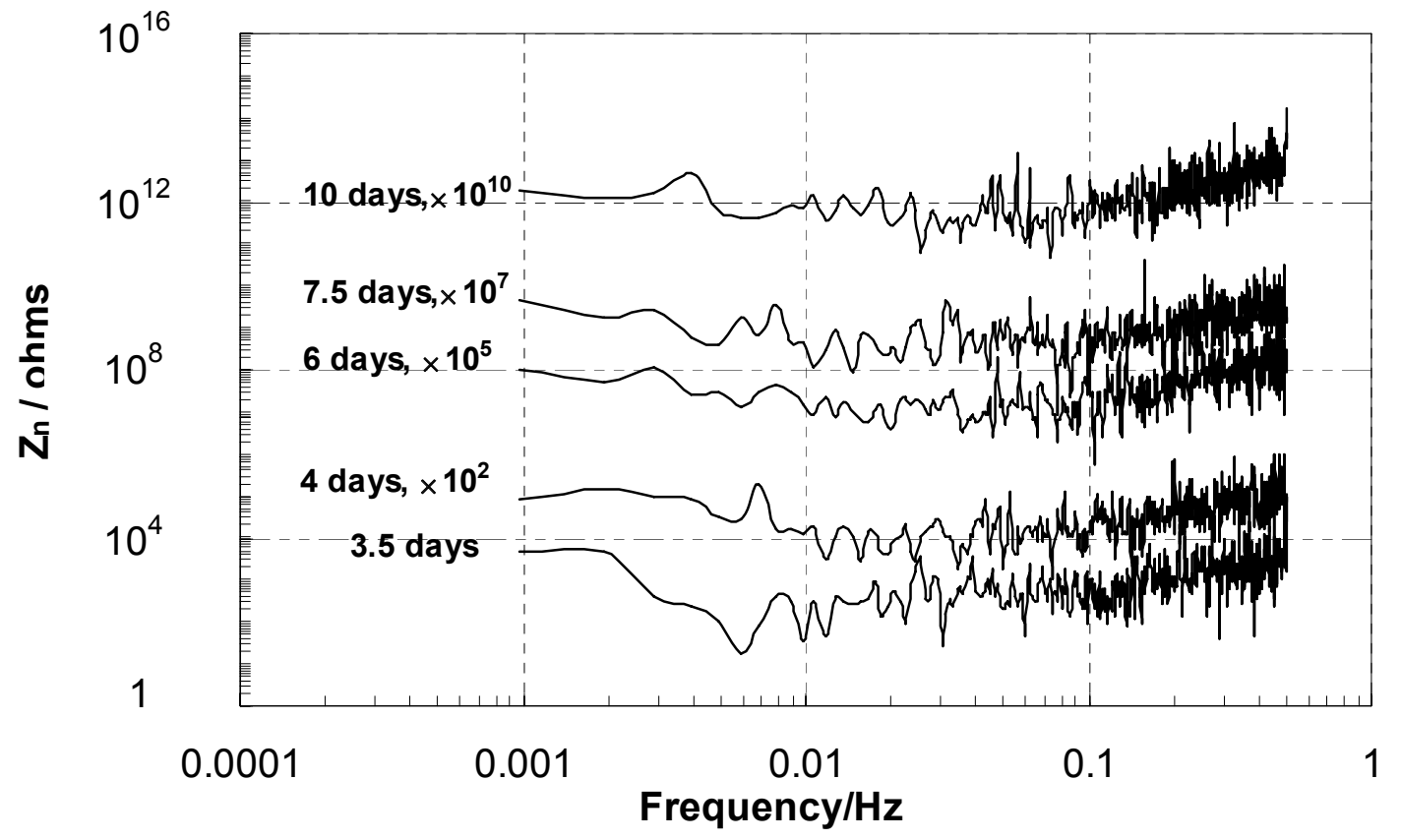

Figure 11. The variation of $Z_{\mathrm{n}}$ with time for $11.6 \mathrm{~cm}^{2}$ specimens in $1 \% \mathrm{NaCl}$ solution 

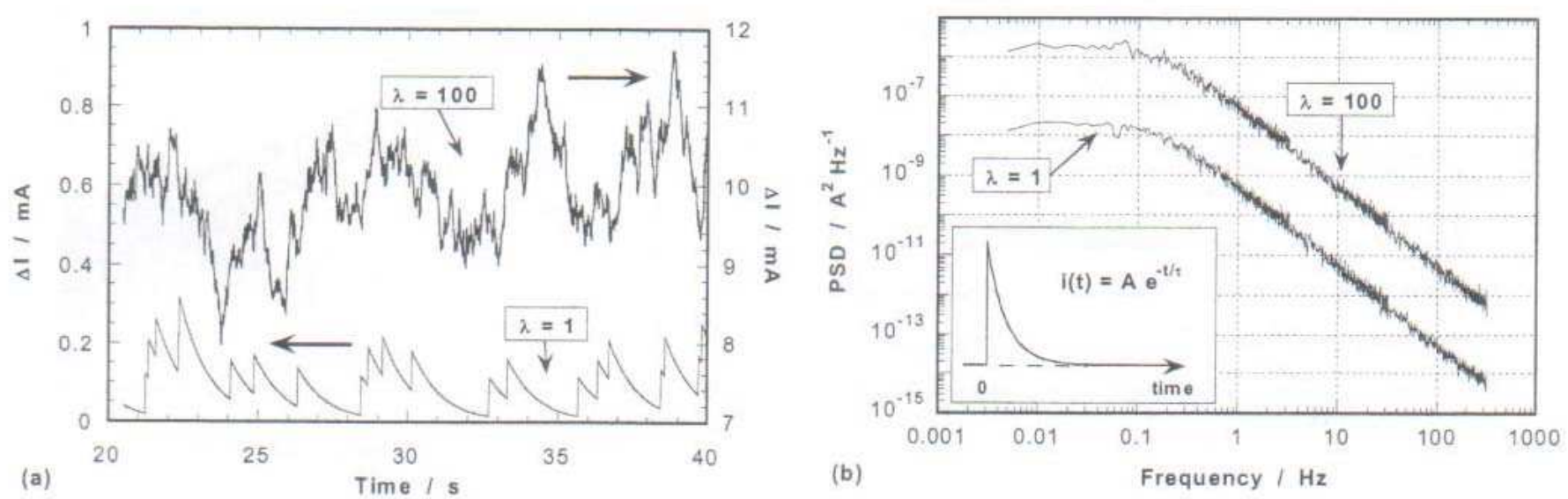

Figure 12. Influence of the number of transients on (a) the time record and (b) PSD. Simulations of randomly occurring exponentially decaying transients defined in the inset for two values of the transients average rate: $\lambda=1$ and $100 \mathrm{~s}^{-1}\left(\mathrm{~A}=10^{-4} \mathrm{~A}, \tau=1 \mathrm{~s}\right)^{6}$ 